Supplementing Information

\title{
Redox Catalytic and Quasi-Solid Sulfur Conversion for High Capacity Lean Lithium Sulfur Batteries
}

\author{
Ke Lu, ${ }^{\dagger}$ Yuzi Liu, ${ }^{\ddagger}$ Junzheng Chen, ${ }^{\S}$ Zhengcheng Zhang," Y Yingwen Cheng ${ }^{\dagger, *}$ \\ ${ }^{\dagger}$ Department of Chemistry and Biochemistry, Northern Illinois University, DeKalb, \\ Illinois 60115, United States \\ $\$$ Center for Nanoscale Materials, Argonne National Laboratory, Lemont, IL 60439, \\ United States \\ § $24 \mathrm{M}$ Technologies, Inc. Cambridge, MA 02139, United States \\ "Chemical Sciences and Engineering Division, Argonne National Laboratory, \\ Lemont, IL, 60439, United States \\ *E-mail: ycheng@niu.edu
}




\section{Calculations of changes in Gibbs free energy $(\Delta G)$ for reactions between relevant $\mathrm{Lix}_{\mathrm{x}} \mathrm{Mog}_{6} \mathrm{~S}_{8}$ and polysulfides.}

We used the following standard data from Ref. [1, 2]

\begin{tabular}{|c|c|}
\hline $4 \mathrm{Li}+\mathrm{S}_{8} \leftrightarrow 2 \mathrm{Li}_{2} \mathrm{~S}_{4}$ & $\Delta \mathrm{G}=-887 \mathrm{~kJ} \mathrm{~mol}^{-1}$ \\
\hline $2 \mathrm{Li}+\mathrm{Li}_{2} \mathrm{~S}_{4} \leftrightarrow 2 \mathrm{Li}_{2} \mathrm{~S}_{2}$ & $\Delta \mathrm{G}=-387 \mathrm{~kJ} \mathrm{~mol}$ \\
\hline $2 \mathrm{Li}+\mathrm{Li}_{2} \mathrm{~S}_{2} \leftrightarrow 2 \mathrm{Li}_{2} \mathrm{~S}$ & $\Delta \mathrm{G}=-480 \mathrm{~kJ} \mathrm{~mol}$ \\
\hline $2 \mathrm{Li}+\mathrm{Li}_{2} \mathrm{~S}_{8} \leftrightarrow \mathrm{Li}_{2} \mathrm{~S}_{6}+\mathrm{Li}_{2} \mathrm{~S}_{2}$ & $\Delta \mathrm{G}=-442 \mathrm{~kJ} \mathrm{~mol}$ \\
\hline
\end{tabular}

Since we were unable to locate reliable standard data for the following reactions, we combined with experimental data (based on average battery voltage) and determined the changes in Gibbs free energies as:

\begin{tabular}{|c|c|}
\hline $2 \mathrm{Li}+\mathrm{S}_{8} \leftrightarrow \mathrm{Li}_{2} \mathrm{~S}_{8}$ & $\Delta \mathrm{G}=-463 \mathrm{~kJ} \mathrm{~mol}^{-1}$ \\
\hline $8 \mathrm{Li}+3 \mathrm{~S}_{8} \leftrightarrow 4 \mathrm{Li}_{2} \mathrm{~S}_{6}$ & $\Delta \mathrm{G}=-1721 \mathrm{~kJ} \mathrm{~mol}^{-1}$ \\
\hline $10 \mathrm{Li}+\mathrm{Li}_{2} \mathrm{~S}_{6} \leftrightarrow 6 \mathrm{Li}_{2} \mathrm{~S}$ & $\Delta \mathrm{G}=-1830 \mathrm{~kJ} \mathrm{~mol}$ \\
\hline $6 \mathrm{Li}+\mathrm{Li}_{2} \mathrm{~S}_{4} \leftrightarrow 4 \mathrm{Li}_{2} \mathrm{~S}$ & $\Delta \mathrm{G}=-1152 \mathrm{~kJ} \mathrm{~mol}^{-1}$ \\
\hline $2 \mathrm{Li}+\mathrm{Li}_{1} \mathrm{Mo}_{6} \mathrm{~S}_{8} \leftrightarrow \mathrm{Li}_{3} \mathrm{Mo}_{6} \mathrm{~S}_{8}$ & $\Delta \mathrm{G}=-415 \mathrm{~kJ} \mathrm{~mol}^{-1}$ \\
\hline $\mathrm{Li}+\mathrm{Li}_{3} \mathrm{Mo}_{6} \mathrm{~S}_{8} \leftrightarrow \mathrm{Li}_{4} \mathrm{Mo}_{6} \mathrm{~S}_{8}$ & $\Delta \mathrm{G}=-178 \mathrm{~kJ} \mathrm{~mol}$ \\
\hline
\end{tabular}

Calculated Gibbs free energies $(\Delta \mathrm{G})$ of relevant redox reactions between $\mathrm{Li}_{\mathrm{x}} \mathrm{Mo}_{6} \mathrm{~S}_{8}$ and lithium polysulfide species by combining the above data:

\begin{tabular}{|c|c|}
\hline $\mathrm{Li}_{3} \mathrm{Mo}_{6} \mathrm{~S}_{8}+\mathrm{S} \leftrightarrow \mathrm{Li}_{1} \mathrm{Mo}_{6} \mathrm{~S}_{8}+\mathrm{Li}_{2} \mathrm{~S}_{8}$ & $\Delta \mathrm{G}=-48 \mathrm{~kJ} \mathrm{~mol}^{-1}$ \\
\hline $\mathrm{Li}_{3} \mathrm{Mo}_{6} \mathrm{~S}_{8}+\mathrm{S} \leftrightarrow \mathrm{Li}_{1} \mathrm{Mo}_{6} \mathrm{~S}_{8}+\mathrm{Li}_{2} \mathrm{~S}_{6}$ & $\Delta \mathrm{G}=-52 \mathrm{~kJ} \mathrm{~mol}^{-1}$ \\
\hline $\mathrm{Li}_{3} \mathrm{Mo}_{6} \mathrm{~S}_{8}+\mathrm{S} \leftrightarrow \mathrm{Li}_{1} \mathrm{Mo}_{6} \mathrm{~S}_{8}+\mathrm{Li}_{2} \mathrm{~S}_{4}$ & $\Delta \mathrm{G}=-58 \mathrm{~kJ} \mathrm{~mol}$ \\
\hline $\mathrm{Li}_{4} \mathrm{Mo}_{6} \mathrm{~S}_{8}+\mathrm{Li}_{2} \mathrm{~S}_{6} \leftrightarrow \mathrm{Li}_{3} \mathrm{Mo}_{6} \mathrm{~S}_{8}+\mathrm{Li}_{2} \mathrm{~S}$ & $\Delta \mathrm{G}=-50 \mathrm{~kJ} \mathrm{~mol}$ \\
\hline $\mathrm{Li}_{4} \mathrm{Mo}_{6} \mathrm{~S}_{8}+\mathrm{Li}_{2} \mathrm{~S}_{4} \leftrightarrow \mathrm{Li}_{3} \mathrm{Mo}_{6} \mathrm{~S}_{8}+\mathrm{Li}_{2} \mathrm{~S}$ & $\Delta \mathrm{G}=-84 \mathrm{~kJ} \mathrm{~mol}^{-1}$ \\
\hline $\mathrm{Li}_{4} \mathrm{Mo}_{6} \mathrm{~S}_{8}+\mathrm{Li}_{2} \mathrm{~S}_{2} \leftrightarrow \mathrm{Li}_{3} \mathrm{Mo}_{6} \mathrm{~S}_{8}+\mathrm{Li}_{2} \mathrm{~S}$ & $\Delta \mathrm{G}=-124 \mathrm{~kJ} \mathrm{~mol}$ \\
\hline
\end{tabular}



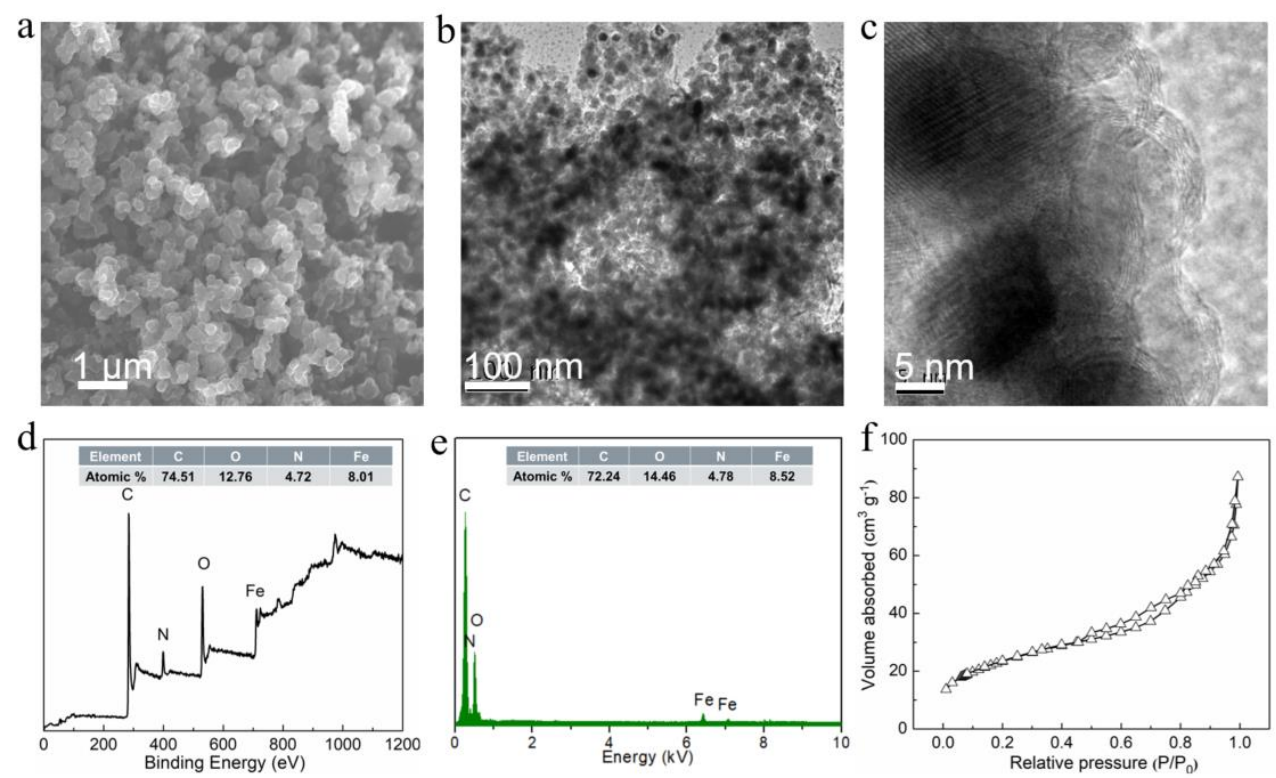

Figure S1: Characterization of the $\mathrm{Fe}_{3} \mathrm{O}_{4}-\mathrm{NC}$ host: (a) SEM and (b,c) TEM images; (d) XPS spectrum, (e) EDX spectrum and (f) nitrogen adsorption-desorption isotherm.

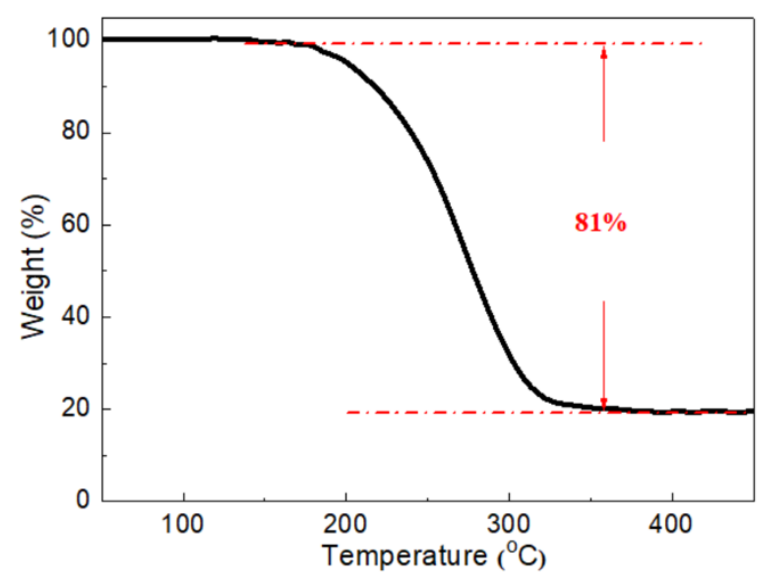

Figure S2: TGA analysis of sulfur impregnated in $\mathrm{Fe}_{3} \mathrm{O}_{4}-\mathrm{NC}$ nanocomposite. The sulfur loading was $\sim 81 \mathrm{wt} \%$. 

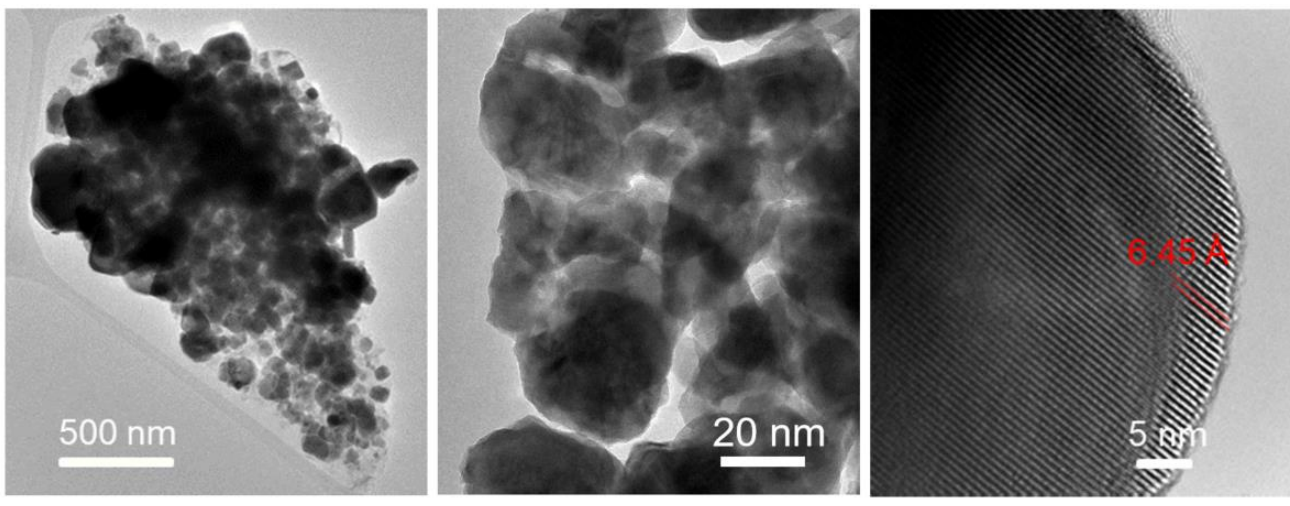

Figure S3: TEM images of $\mathrm{Mo}_{6} \mathrm{~S}_{8} /$ carbon nanoparticles.

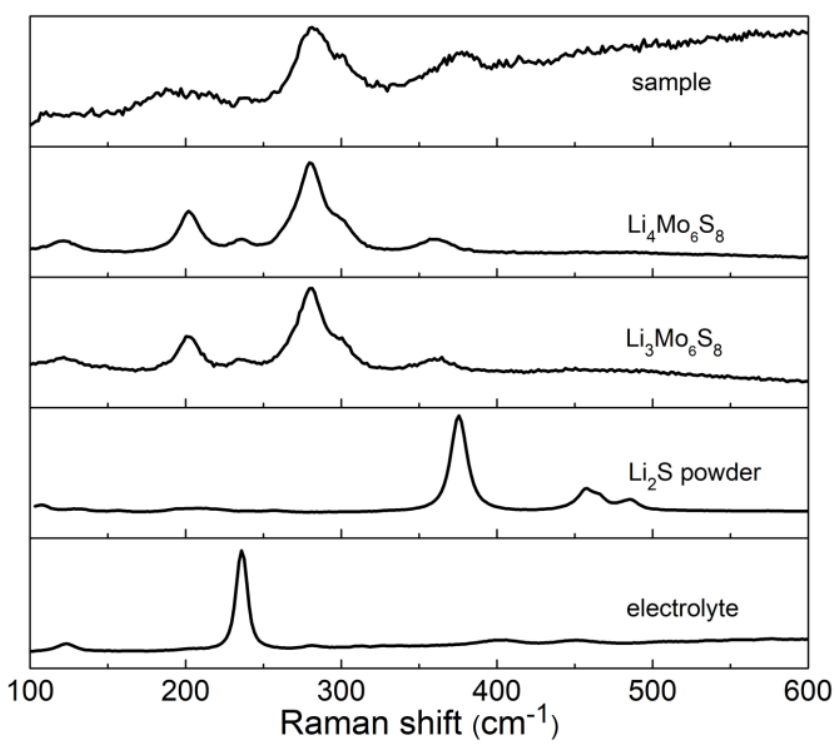

Figure S4: Raman spectrum of the $\mathrm{Li}_{4} \mathrm{Mo}_{6} \mathrm{~S}_{8}$ electrode after reacting with $\mathrm{Li}_{2} \mathrm{~S}_{4}$ as explained in Figure 1. The spectra of relevant standard materials are included for comparison, which confirms presence of $\mathrm{Li}_{2} \mathrm{~S}$ in the sample.
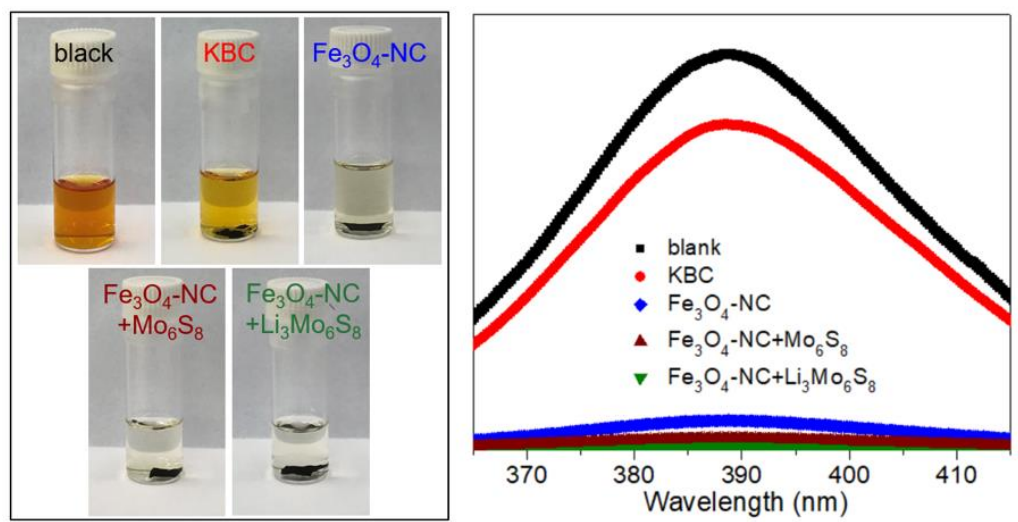

Figure S5: Lithium polysulfide absorption test under static condition. The test was performed inside a glove box using $5 \mathrm{mM} \mathrm{Li}_{2} \mathrm{~S}_{4}$ solution, which was prepared by mixing $\mathrm{Li}_{2} \mathrm{~S}$ and elemental sulfur at a molar ratio of 1:3 in DME/DOL. Electrodes of 
approximately $1.0 \mathrm{~cm}^{2}$, prepared by either $\mathrm{S} @ \mathrm{KBC}$ (ketjen black carbon), $\mathrm{S} @ \mathrm{Fe}_{3} \mathrm{O}_{4}-$ $\mathrm{NC}, \mathrm{Mo}_{6} \mathrm{~S}_{8}+\mathrm{S} @ \mathrm{Fe}_{3} \mathrm{O}_{4}-\mathrm{NC}$ and or $\mathrm{Li}_{3} \mathrm{Mo}_{6} \mathrm{~S}_{8}+\mathrm{S} @ \mathrm{Fe}_{3} \mathrm{O}_{4}-\mathrm{NC}$ were immersed in $3 \mathrm{~mL}$ of $\mathrm{Li}_{2} \mathrm{~S}_{4}$ solution in separate vials. The solutions were allowed to rest for $30 \mathrm{~min}$ and the photographs were taken for comparison of the colors. The solution was also analyzed via $\mathrm{UV}-\mathrm{Vis}$ adsorption spectroscopy.

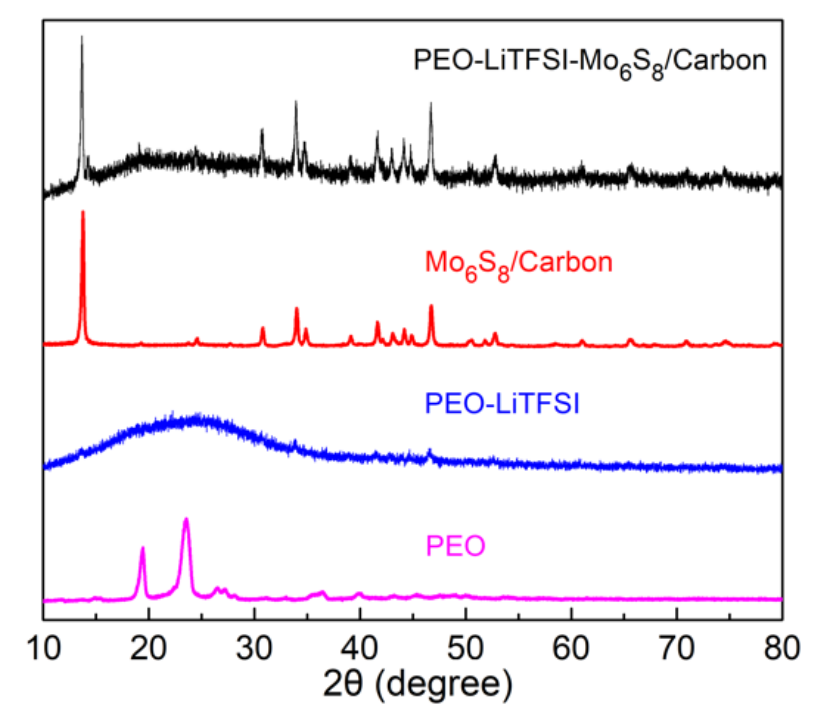

Figure S6: X-ray diffraction pattern of relevant materials as noted. The assynthesized $\mathrm{PEO}_{10}$-LiTFSI binder was amorphous and this amorphous structure was maintained when assembled in electrodes with $\mathrm{Mo}_{6} \mathrm{~S}_{8}$. 

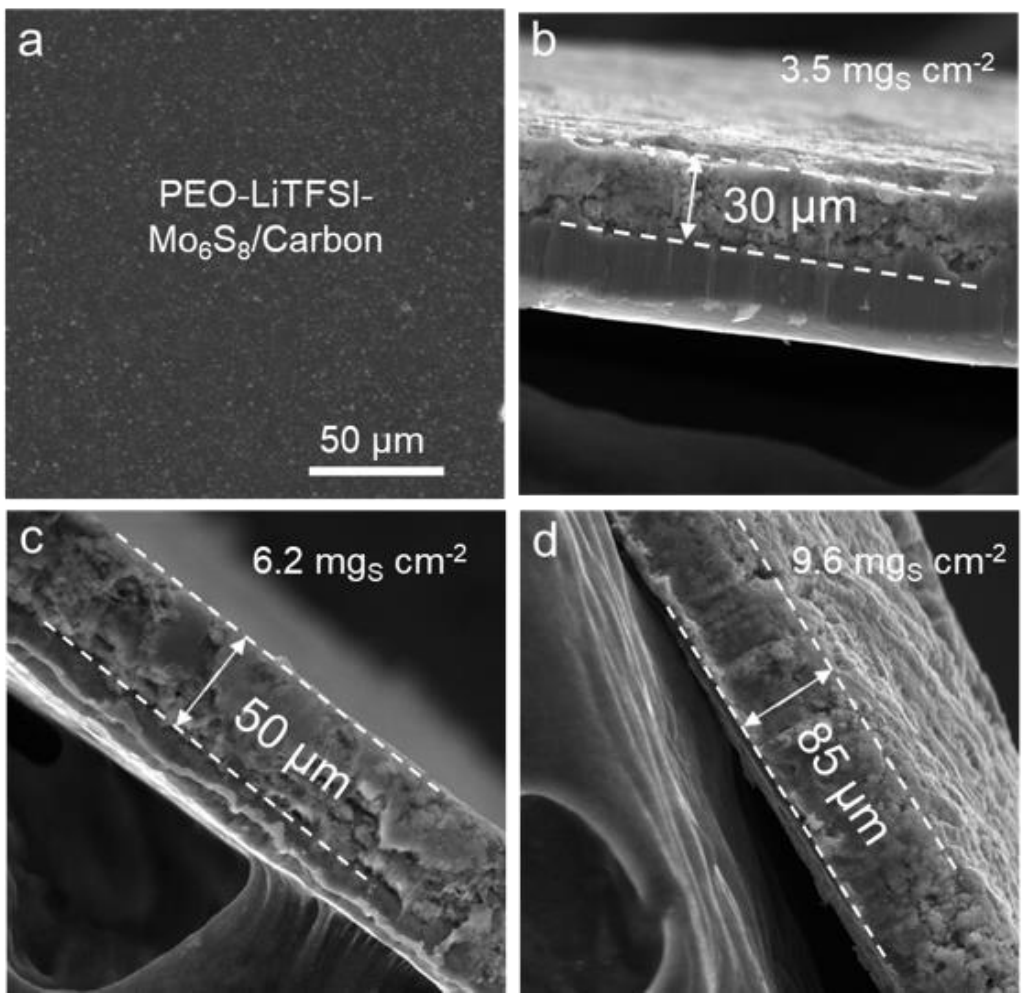

Figure S7: SEM images of a) PEO-LiTFSI-Mo ${ }_{6} \mathrm{~S}_{8}$ composites and b-d) cross-section SEM image of $\mathrm{S} @ \mathrm{Mo}_{6} \mathrm{~S}_{8}+\mathrm{Fe}_{3} \mathrm{O}_{4}-\mathrm{NC}$ sulfur cathodes with different sulfur loading as noted.
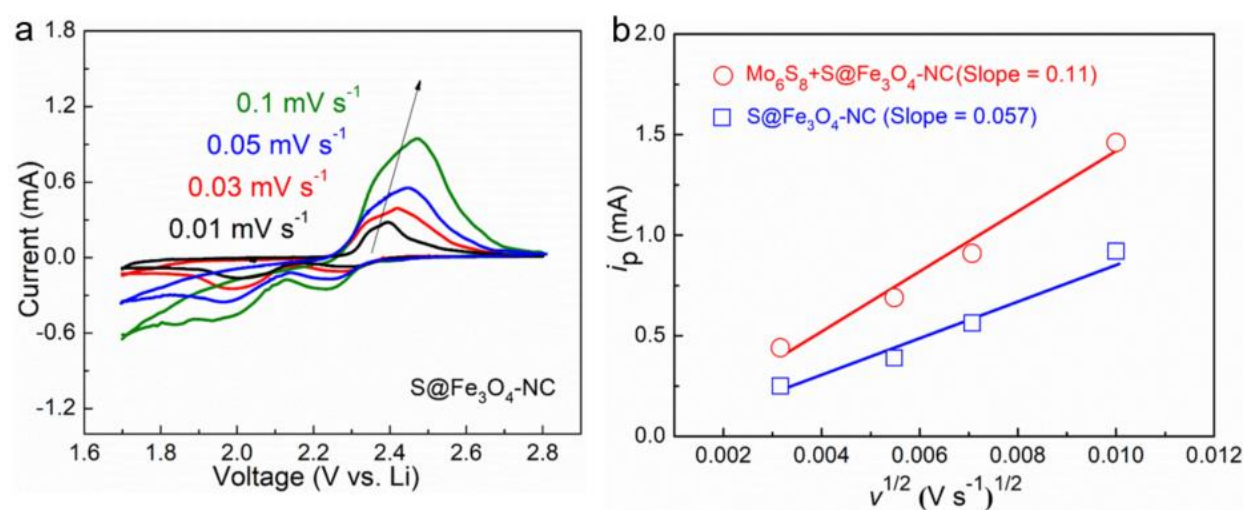

Figure S8: a) CVs of the sulfur cathodes without the $\mathrm{Mo}_{6} \mathrm{~S}_{8}$ mediator at different scan rates. b) relationships between the anodic peak currents $\left(i_{p}\right)$ at $\sim 2.4 \mathrm{~V}$ and square root of the scan rates for different sulfur cathodes as noted. The linear relationship suggests a diffusion-controlled electrochemical process and the slope is directly related with $\mathrm{Li}$-ion diffusion coefficient. 


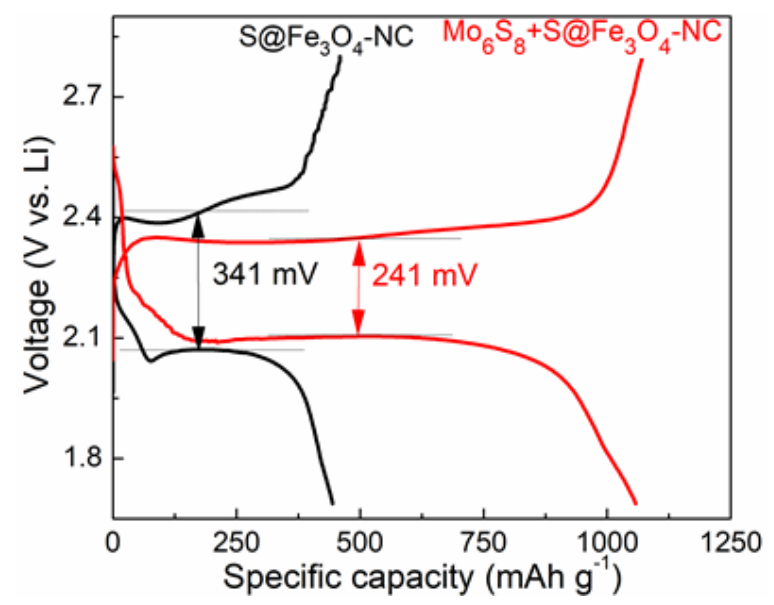

Figure S9: Voltage profiles of sulfur cathodes with and without the $\mathrm{Mo}_{6} \mathrm{~S}_{8}$ mediator at $0.3 \mathrm{~mA} \mathrm{~cm}^{-2}$ and $25^{\circ} \mathrm{C}$. The E/S ratio was 4.2 .

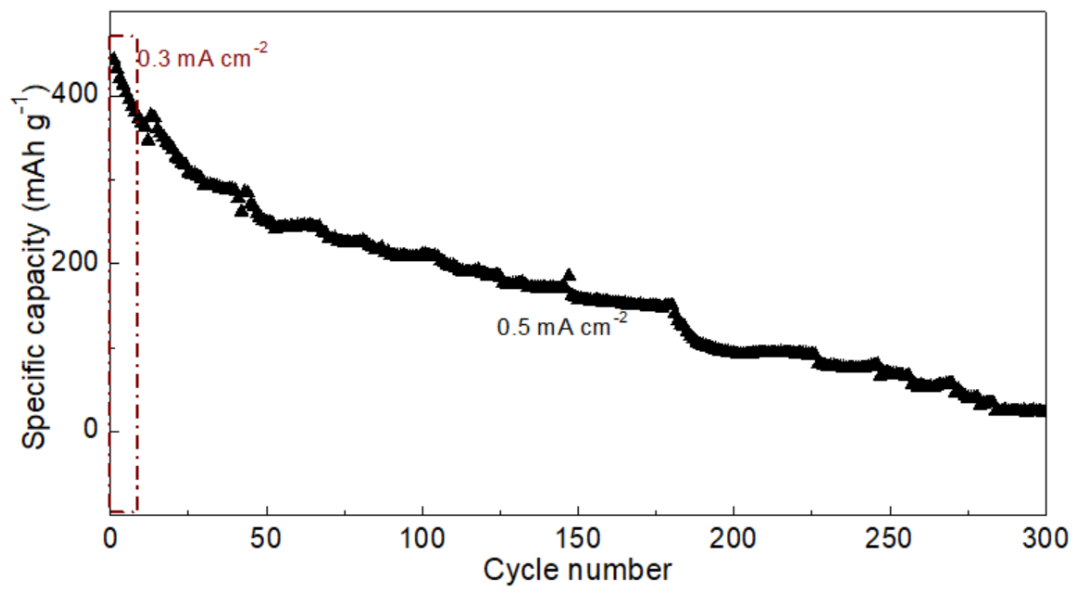

Figure S10: Cycling stability of sulfur cathode without the $\mathrm{Mo}_{6} \mathrm{~S}_{8}$ mediator tested at $25^{\circ} \mathrm{C}$. The E/S ratio was $4.2 \mu \mathrm{L} \mathrm{mg}^{-1}$ and sulfur loading was $3.8 \mathrm{mg} \mathrm{cm}^{-2}$. 


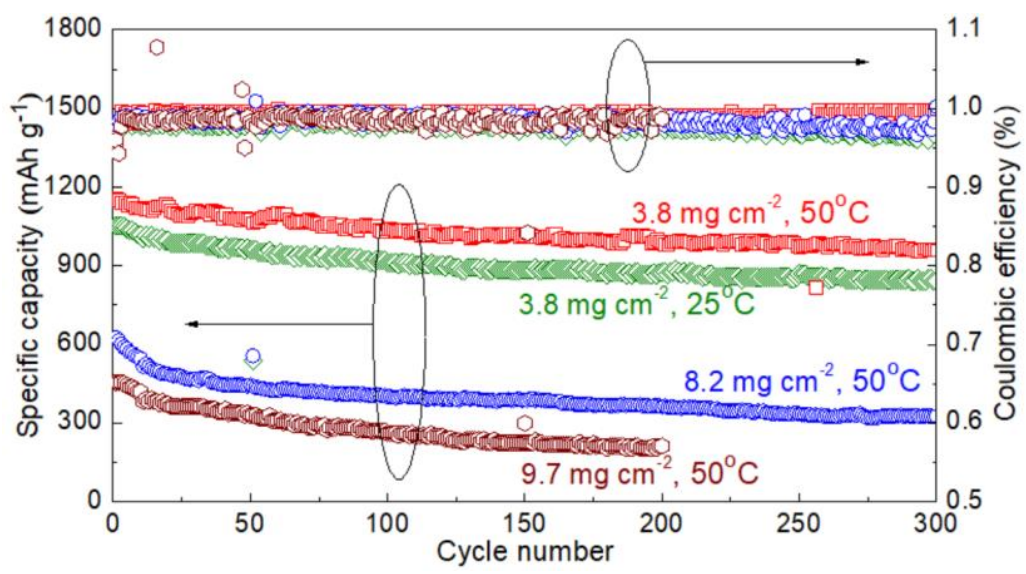

Figure S11: Cycling stability and the corresponding Coulombic Efficiency of high loading sulfur cathodes containing $\mathrm{Mo}_{6} \mathrm{~S}_{8}$ at 25 and $50{ }^{\circ} \mathrm{C}$.

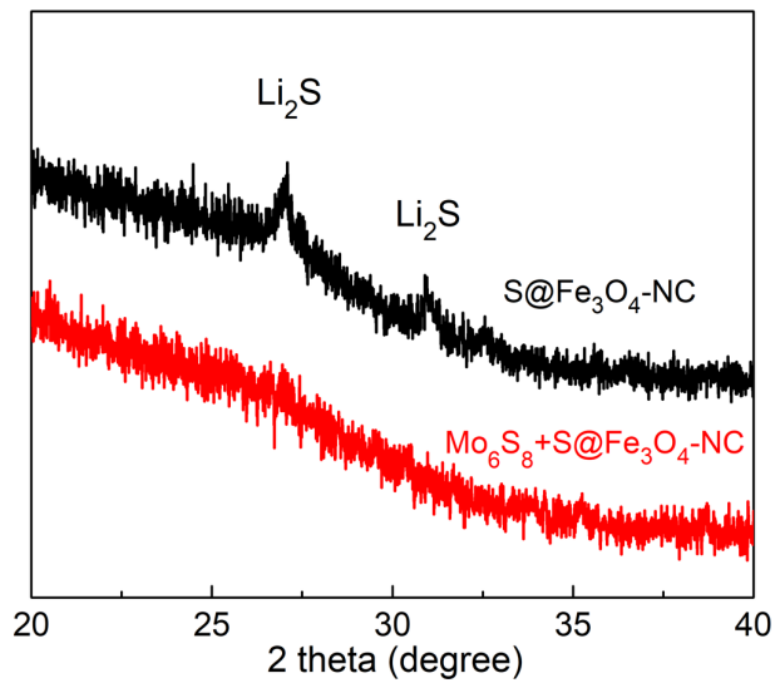

Figure S12: X-ray diffraction patterns of sulfur cathodes isolated from cycled lean Li$\mathrm{S}$ batteries. No measurable $\mathrm{Li}_{2} \mathrm{~S}$ diffraction peaks was observed for cathodes containing the $\mathrm{Mo}_{6} \mathrm{~S}_{8}$ mediator. 

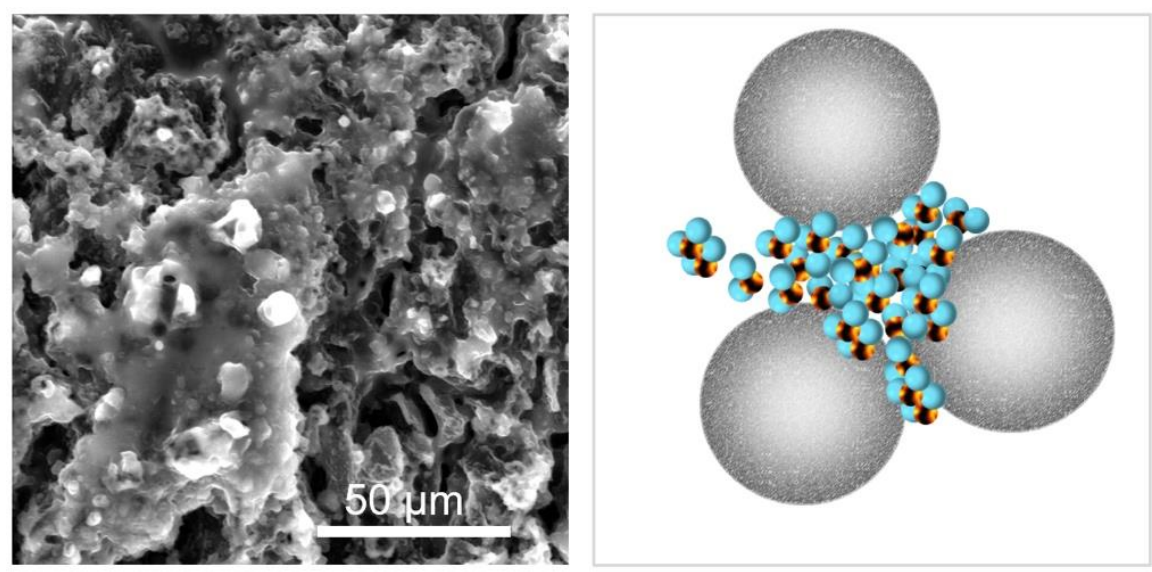

Figure S13: SEM image and a schematic illustration of the sulfur cathode cycled without the $\mathrm{Mo}_{6} \mathrm{~S}_{8}$ mediator under an E/S ratio of 4.2. The accumulation of large volume $\mathrm{Li}_{2} \mathrm{~S}$ was evident.

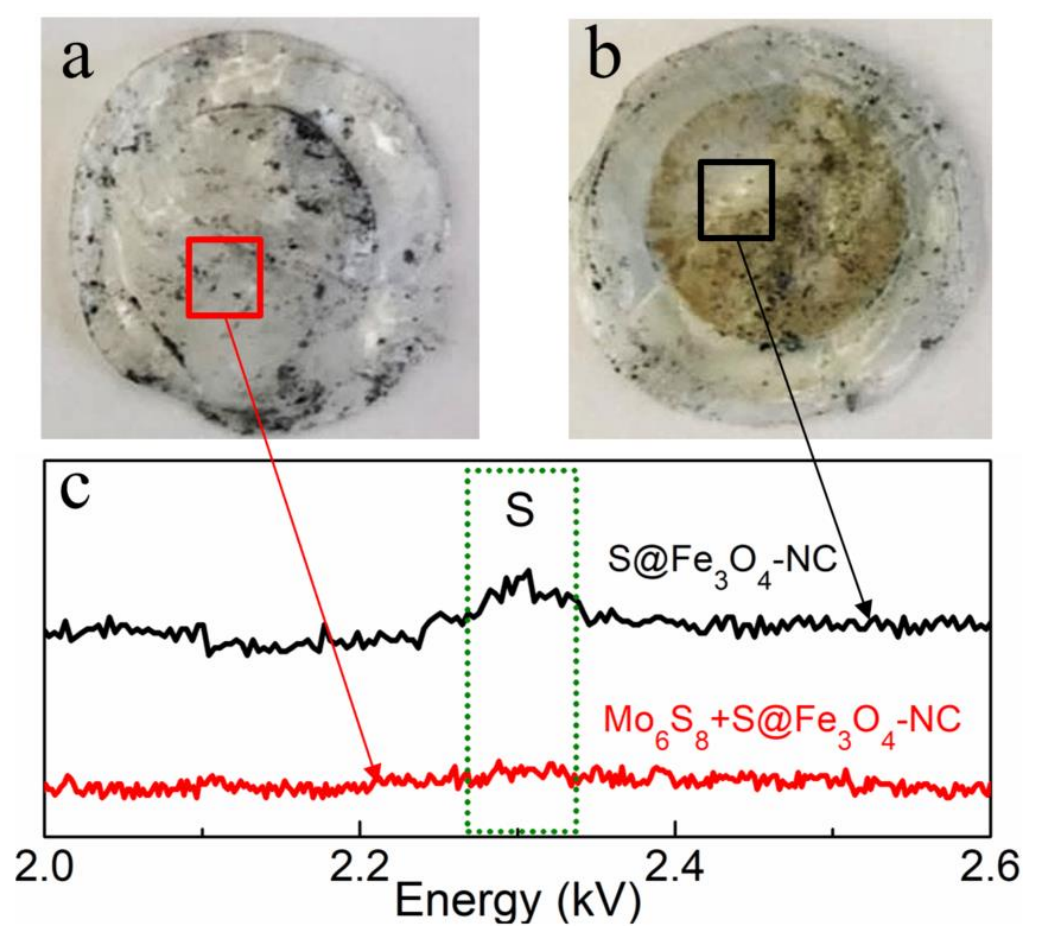

Figure S14: Photographs of the separator on sulfur cathode side (a: with $\mathrm{Mo}_{6} \mathrm{~S}_{8}, \mathrm{~b}$ : without $\mathrm{Mo}_{6} \mathrm{~S}_{8}$ ) after cycling under the E/S ratio of 4.2. (c) EDX spectra of the selected area in (a) and (b). 

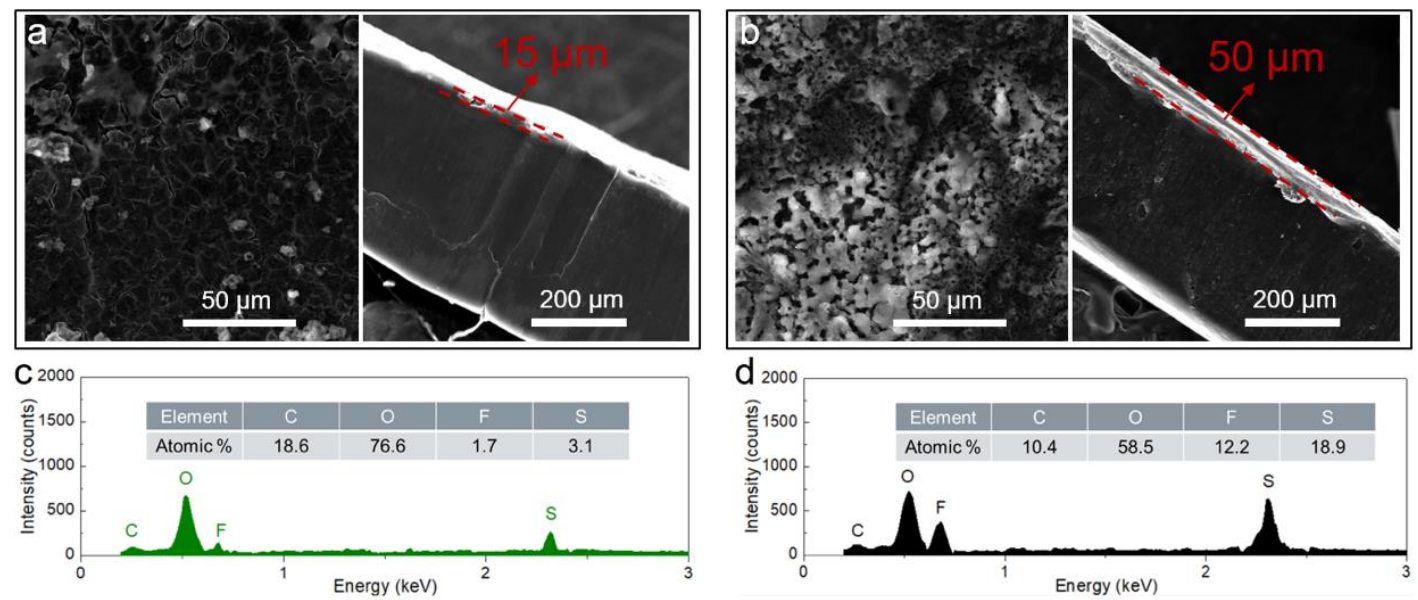

Figure S15: (a,b) SEM images and (c,d) EDX spectra of Li metal anodes cycled using sulfur cathodes $(a, c)$ with and $(b, d)$ without the $\mathrm{Mo}_{6} \mathrm{~S}_{8}$ mediator.

\section{References}

1. Wang, L.; Zhang, T.; Yang, S.; Cheng, F.; Liang, J.; Chen, J., A Quantum-

Chemical Study on the Discharge Reaction Mechanism of Lithium-Sulfur Batteries. $J$. Energy Chem. 2013, 22, 72-77.

2. Gocke, E.; Schoellhorn, R.; Aselmann, G.; Mueller-Warmuth, W., Molybdenum Cluster Chalcogenides $\mathrm{Mo}_{6} \mathrm{X}_{8}$ : Intercalation of Lithium via Electron/Ion Transfer. Inorg. Chem. 1987, 26, 1805-1812. 